\title{
Chin Kee Onn's Ma-rai-ee and the Narration of the Malayan Nationalist Subject in the Aftermath of the Pacific War
}

\section{Su Fang Ng}

University of Michigan, Ann Arbor, USA

On 15 February 1942, after 123 years of British rule, Singapore, touted as an inpenetrable fortress, the Gibraltar of the East and one of the four Bastions of the British Empire, fell to the lightning Japanese advance that took a mere seventy days down the Malay Peninsula from the Thai border. On 15 August 1945, after the Americans had dropped the devastating nuclear bombs on Hiroshima and Nagasaki, the Japanese finally surrendered to the British. Between those two dates everything in Malaya changed.

The Japanese Occupation was Malaya's first national trauma. ${ }^{1}$ It both formed the modern independent nation of Malaysia (which included, for a time, Singapore) and contributed to the break-up of the nation into the current components of Malaysia and Singapore shortly after in 1963. It also deepened racial tensions, culminating in the riots of 13 May 1969. The historian of the occupation has no lack of materials: the Pacific War inspired a great body of writings in diverse genres by both British and Malayan authors. ${ }^{2}$ While the experiences of Europeans in Malaya have been studied at length, there is a need to learn more about local responses to Japanese rule, some of which are still being produced. ${ }^{3}$ In this paper, I examine Chin Kee Onn's novel, Ma-rai-ee (1952), which narrates the period of the Japanese Occupation to critique Japanese imperialism explicitly and British colonialism implicitly, and thus reconceptualizes the relationship between European colonials and Malayans as a more equal one. Chin sees this shared national trauma as both a unifying and a divisive force: on the one hand, the trauma gives rise to a multi-racial resistance against Japanese 
oppression, but on the other hand, it also reveals the people's capacity for treachery and highlights political divisions. I argue that with $\mathrm{Ma}$-rai-ee, Chin attempts to construct a nationalist subjectivity, exploring, and even prescribing, what it means to be a post-colonial citizen. ${ }^{4}$ In the process, he imagines a new multi-racial community into being, to paraphrase Benedict Anderson's powerful formulation. ${ }^{5}$

$M a-r a i-e e$ is the first English-language fictional treatment of the war by a Malayan. ${ }^{6}$ It is Chin's first novel, but his second account of the Pacific War. His first is a non-fictional analysis, Malaya Upside Down (1946), published soon after the Japanese surrender and written secretly during the occupation. In his Preface, Chin says, "This book was written under the constant shadow of death, for literally, walls had ears, and spies were among the best of 'friends'. Such were the circumstances, and so many the pitfalls, that if there were but one unguarded action, one careless move in the quest for information - then this book would never have been completed!"' This sense of being surrounded by the danger of betrayal would colour his novel and its portrayal of an underground resistance group composed of a small number of survivors from a massacre at a tin mine sheltering more than a hundred people fleeing the bombing in the city of Ipoh. Malaya Upside Down is an early articulation of many of the issues that Chin would raise again in Ma-rai-ee. If Malaya Upside Down is in many ways a formulation of the problem of the lack of national unity exposed so dramatically by the war, then the first-person narrative Ma-rai$e e$ is a fictional depiction of a possible solution.

As an analysis of the causes and the consequences of British defeat, Malaya Upside Down is not simply a chronicle of Japanese brutality. It is unflinching in its consideration of the havoc created by local looters during the period in between British retreat and the establishment of Japanese military rule, of the black marketeering and of the activities of Japanese collaborators. Although Chin emphasizes the endurance of the local people, it seems to me that an underlying current of both his works intimates that the historical record of the Japanese period is also a record of local failures, of which the most crucial one is national disunity. In his list of the causes of British defeat in Malaya Upside Down, Chin frames the problem of national disunity in terms of racial heterogeneity:

The fifth contributory cause was the cosmopolitanism of Malaya. There was no such thing as "national consciousness" concerning Malaya. Here we find people who consider themselves, particularly the Chinese, as "guests and sojourners". They are peace-loving folk who are not interested in "total war". Look at the multiplicity of races found in Malaya before the war: Malays, Chinese, Indians, Ceylonese, Burmese, Thais, Arabs, Jews, Javanese, Japanese, Russians, Australians, British, Dutch, Italians, Germans, Hungarians, Czechs, Eurasians, Filipinos, and a sprinkling of other peoples not 
already enumerated. Excepting the Malays they all came to Malaya for trade and commerce. It matters little to them who rules the country, as long as they get freedom and justice. Therefore, there was no Home Front in Malaya. The people were not organised for total resistance and total war. There was no such thing as defending Malaya to the last man. (p. 6)

The sheer length of the list of races suggests a multiplicity gone out of control. Long as it is, the list still cannot account for everybody. At best, it is a multitude difficult to mobilize for war. Racial heterogeneity need not always preclude national unity, of course. The problem, rather, is the absence of "national consciousness". In the Malayan context, according to Chin, this absence is linked with racial heterogeneity.

In Ma-rai-ee, Chin very self-consciously constructs a multi-racial community by including the Malay Halisamat and the Indian Jangitta Singh in his cast of characters though the novel is set in the Chinese-populated tinmining region of the Kinta Valley and though most of his characters are Chinese. In his depiction of a multi-racial community united by their shared sufferings during the occupation and in their resistance against Japanese rule, Chin provides a counter-discourse against accusations of local apathy and factionalism. When Ah Fui does not return from his trip to a nearby European-owned rubber estate to get medicine for the sick children, a search-party is organized to look for him. Both Jangitta and Halisamat volunteer to accompany the other men:

The Sikh jaga, ${ }^{8}$ Jangitta Singh, hearing of the proposed expedition, explained that he should accompany us, for he had been informed that gangs of Indians were on the prowl, so that his presence with us would be an advantage to the party. Halisamat, the chauffeur, who was attached to Kwan Lo and was deeply concerned over the condition of the children, said that he also had heard that gangs of Malays were on the rampage. Therefore, he should accompany the party. "Malays don't kill Malays or the friends of Malays," he remarked confidently. (p. 32)

Besides acting as liaisons and emissaries with Indians and Malays for the Chinese, they also have greater freedom of movement. When the members of the search-party manage to secure the needed medicine from the abandoned rubber-estate but find themselves trapped there by the advancing Japanese army, it is Halisamat and Jangitta who offer to get the medicine back to the sick children at the mine: they argue, "We've heard that the Japanese are not hostile towards Malays and Indians" (p. 40). Multiracialism, then, is portrayed as crucial to survival because it offers the flexibility, not to mention protection, that separatism does not.

Multi-racialism is more than just a temporary measure. The ultimate lesson is that only a multi-racial community can resist external threats. Later, Halisamat and Jangitta join the C.I.D. and the police force respectively in order to help with the resistance effort by infiltrating the Japanese administration, while the Chinese in the group work outside the official 
system, sounding out friends in high places, inciting the lower classes and distributing anti-Japanese pamphlets. This ideal multi-racial community is contrasted with the armed gang robbers who travel with members of their own race and prey on Malayans of other races.

The lack of cohesiveness that Chin represents in part in the form of gang robbers in Ma-rai-ee and that he worries about in Malaya Upside Down is viewed by the Japanese as a weakness that has been exploited by European colonizers. The handbook given to Japanese soldiers sent to Malaya explains: "The reason why so many peoples of the Far East have been so completely crushed by so few white men is, fundamentally, that they have exhausted their strength in private quarrels, and that they are lacking in any awareness of themselves as a group, as peoples of Asia". The Japanese rhetoric of Asian solidarity, however, has its contradictions:

we must at the very least, here in Asia, beat these Westerners to submission, that they may change their arrogant and ill-mannered attitude.

The present war is a struggle between races, and we must achieve the satisfaction of our just demands with no thought of leniency to Europeans, unless they be the Germans and Italians.

Although initially it may appear that there are two great opposing races involved in this struggle - Asian and European - the enemies cannot be separated by race, after all. As the Germans and Italians are the "exceptions" to the oppressive Europeans, so are the "Overseas Chinese" to the dominated Asians:

these people [the overseas Chinese], by a variety of clever schemes concerted with the European administrators, are steadily extorting money from the native population, and that the greater part of the natives' resentment is directed against them rather than against the Europeans; and, secondly, that for the most part they have no racial or national consciousness, and no enthusiasms outside the making of money. ${ }^{9}$

By writing the story of Malayan resistance to Japanese imperialism, Chin Kee Onn seeks to counter accusations like these. For Chin, it is not Asian solidarity that must be achieved, but rather, a specifically Malayan one. His novel shows how the Malayan national identity develops under the pressure of Japanese oppression. Interrogated by Japanese soldiers prior to the massacre, the owner of the tin-mine, speaking pidgin English to placate the Japanese, identifies Malaya as his homeland: "I come Malaya when very small. I live Malaya over forty year. When old I die in Malaya. I now belong Malaya" (p. 53).

Ironically, the Japanese occupation galvanizes a sense of national identity in a way not anticipated by the Japanese. ${ }^{10}$ In Ma-rai-ee, the Japanese propaganda sheets distributed from the air by plane announcing that "The Victorious and Invincible Nippon Imperial Army having come to liberate Malai to the establishment of the Co-Prosperity Sphere of Asia 
for Asiatics" (p. 19) only provoke scepticism. It is as if this scepticism acts as the glue that unifies Malayans. It certainly helps to motivate the characters' shift from passivity to a more active resistance, though true resistance will only develop after the massacre at the tin-mine in response to Japanese brutality when the survivors seek vengeance. Chin is more pointed in his criticism of Japanese hypocrisy in Malaya Upside Down, where he notes that while the Japanese propaganda machinery proclaims, "Down with Anglo-Americanism!" or "Asia for Asiatics!" and "Asiatics must go back to Asiatic ways", and touts Nippon's new order for "Co-prosperity and Fraternity", the Japanese in fact enjoy modern Western products, living like white men and conquerors in Malaya, while their women dress like white women. Chin writes:

Japanese modernism is nothing but a copy of western modernity. On the one hand they ranted: "Throw off all Anglo-American influences". But, on the other, they showed too plainly they themselves could not get along without Anglo-American amenities, and Anglo-American materials.

It would therefore appear that what the Japanese really desired was that Malayans should be relegated to the seventeenth century, while they alone were privileged to live in the twentieth. ${ }^{11}$

For all races, the period of the Japanese Occupation was one of increasingly severe material deprivation. The gap between the privileged lives of the Japanese and those of Malayans exposes Japanese rule to be no better than British - in fact, far worse. And mutual suffering allows for the forging of a national consciousness, of a nation of Malayans.

It is probably clear by now that Chin's concern with racial heterogeneity has a particular accent, revealed in his discussion of Malayan cosmopolitanism by that short subordinate clause, "particularly the Chinese" (p. 6). Himself an ethnic Chinese, Chin's more narrow project in $\mathrm{Ma-rai-Ee}$ is to develop a Malayan-Chinese nationalist subjectivity within a larger multiracial nation. I argue, however, that racial heterogeneity - a problem that Chin is well aware of and tries to solve - becomes constitutive of the new Malayan nationalism. Thus, while reading to discover the emergence of the new post-colonial nation, we need to be alert to the ways in which empire still haunts this nation. As Benedict Anderson has described in Imagined Communities, the new post-World War II states combine characteristics of different models of nationalism that historically preceded them, namely, the European languages-of-state as in the "American" model, the ardent populism of the linguistic European nationalism, and the Russifying policyorientation from official nationalism. I want here to focus on the last aspect. Anderson takes the example of Indonesia as a more or less successful experiment in "Russification":

Some of the peoples on the eastern coast of Sumatra are not only physically close, across the narrow Straits of Malacca, to the populations on 
the western littoral of the Malay Peninsula, but they are ethnically related, understand each other's speech, have a common religion, and so forth. These same Sumatrans share neither mother-tongue, ethnicity, nor religion with the Ambonese, located on islands thousands of miles away to the east. Yet during this century they have come to understand the Ambonese as fellowIndonesians, the Malays as foreigners.

He attributes this achievement of colonial nationalism to both the school system with Batavia as the Rome of this vast Dutch colony as well as to the Dutch racial classificatory system: the superior Dutch, followed by the vreemde oosterlingen (foreign Orientals), and at the bottom of the scale, the "inlanders". Anderson writes: "From all this, by a sort of sedimentation, inlander - excluding whites, Dutchmen, Chinese, Arabs, Japanese, 'natives,' indigènes, and indios - grew ever more specific in content; until, like a ripe larva, it was suddenly transmogrified into the spectacular butterfly called 'Indonesian' ". 12

I wish to offer Malaysia as a counter-example. The "Russification", or rather, more accurately, the "Malaysianisation" process has been difficult because of the presence of the British-Malayan counterparts of the DutchIndonesian vreemde oosterlingen, "foreign Orientals" - also known by the more bizarre term, "foreign natives" - that Anderson disregards. It may be that prior to Independence, the number of Chinese in British Malaya was more or less equal to the number of Malays. Part of the problem of making Singapore and the Malay Peninsula a single country was that the Chinese majority in Singapore would upset the delicate racial balance. ${ }^{13}$ The large percentage of these "foreign Orientals" who nonetheless have decided to remain in Southeast Asia and indeed some of whom have lived there for a few generations means that the task of achieving national unity is made exceedingly difficult. The problem, as is hinted in Anderson's discussion of Indonesia, is partly the divisive colonial policies of stratifying society and segregating the races mainly through occupation. In her autobiography, Yeap Joo Kim, rather naively, says:

... I could not help viewing Malaya as a country with neat pigeon holes where everything and everyone was slotted in its own place. The various races were gregarious in their occupations. The Indians were predominantly rubber tappers, railway workers, dairy farmers, book-sellers and cloth merchants. The Malays were policemen, drivers, fishermen and office peons. The Chinese were stevedores, traders, hawkers, miners and servants. The Eurasians were government employees. ${ }^{14}$

Yeap's lack of understanding of the political implications of her observation may be attributed to her high social status before the war and her allegiance to British values the result of growing up during the colonial era. This slotting of peoples also occurs at the school level, though admittedly, by the people's wishes. Even today, the primary school system is a superb example of the official manifestation of this tenacious clinging on to ethnic 
origins. Although Bahasa Malaysia, the national language, is a required subject in all schools, the "People's Own Language" policy allows for the various Malay-, Mandarin- and Tamil-medium primary schools to exist (perhaps somewhat incongruously) under the umbrella of the Ministry of Education. English-medium schools were converted into Malay-medium ones but their former colonial status lingers on in the ageing corps of nuns and monks (called sisters and brothers) who continue teaching there. The populace have more or less retained their various mother tongues. When nearly half the population do not share the same ethnicity, language or religion with the other half, and when that difference persists even after the end of colonialism, the task of achieving national unity is made all the more difficult.

In his study of British writing on Southeast Asia, Clive J. Christie suggests that the "tangled greens of the jungle and the permeable network of mud, water and paddy-field, encourage themes as blurred and complex as the landscape itself" so that British writers concentrate on themes of "pourissement, immersion and absorption, normally seen in sensual or political terms". ${ }^{\text {is }}$ While pourissement - a process of hybridization - may be a British concern, for Chin, as we see in his analysis of Malayan cosmopolitanism, the problem is not simply multiplicity in itself but the way the disparate elements remain separate, the way Malayans lack a "national consciousness". The problem is Malaya's failure to achieve hybridity, which would homogenize it in a fashion. Even the Indian and Australian armies brought in to reinforce British troops are sources of weakness:

In sharp contrast to the fanatical ferocity of the Japanese fighting spirit, the British and Australian forces in Malaya, were shaky and insipid. They appeared to be disunited in spirit and cameraderie. The "Aussies" complained that they were let down by the British, while the "Tommies" retaliated that "the men from down under" were shirkers and equally disappointing. The "Anzacs" cursed at the absence of British air-support, and the British cursed at the absence of Australian successes which were promised. Of the Indian Regiments, many were alleged to be contaminated by discontent and alienation by fifth columnists already active within their ranks. There seemed to be no such thing as a United Supreme Command of the Malayan Defence Forces, and while the Japanese acted with promptness and oneness of purpose, the British, the Australians, and the Indians were grousing over one thing or another and still haggling about seniority and priority. (Malaya Upside Down, p. 9)

The disunity of the Allied forces is another evidence of the lack of pourissement. Not only do the various troops remain detached from one another, they also engage in dangerous internal squabbling. Furthermore, the Indian soldiers have been "contaminated" by fifth columnists - Japanese spies so that even as a group they are no longer whole and do not have the admirable "oneness" of the Japanese. 
The issue of "contamination" that Chin raises concerning the Indian Regiments points to the related concern about another sort of pourissement - one that does occur and that poses a danger to national security. On the one hand, the Malayans themselves are not able to achieve the proper pourissement; on the other hand, the Japanese enemy is all too able to meld into the Malayan environment and thus further weaken Malayan defence:

Moreover, the Japanese took advantage of the outward resemblances of the Asiatic races in Malaya. To the inexperienced, it would not be easy to make out by appearance alone whether an Asiatic were Japanese, Chinese, Malay, Thai, or Burmese. So, Japanese soldiers disguised as Chinese or Malay farmers or fishermen, infiltrated towards the south as the vanguard. They mingled with the already disorganised masses. Among the thousands of fleeing fugitives hurrying through rubber-estates, and along the gutted highways, who knows how many were Japanese regulars scurrying along with arms and ammunition in their bundles? It was impossible for the British to sort out the sheep from the goats. The trains were choked; the trunk-roads were crowded; everybody was bound somewhere.

Thus the Japanese exploited civilian disruption, and they ploughed through the country as if going through loose sand. (p. 6)

Perhaps it is even the disparateness of the populace - the "already disorganised masses" that Chin speaks about - that allows for a lethal Japanese pourissement, for a mingling with and a contamination of Malayans.

The distinction between empire and nation that I wish to stress is the singularity of nation and the plurality of empire. If France, as Ernest Renan argues to prove his distinction between race and nationality, has been able to subsume many races within its national boundaries, it is because the French have forgotten their ethnicity and now have new African immigrants from former colonies on whom to focus their nationalist animosity, which is shaped, for all its nationalism, supremely by race. I do not want to push this too far and make the mistake of conflating nation with race. There is much to be said about Renan's principles of what constitutes a nation: "One is the possession in common of a rich legacy of memories; the other is present-day consent, the desire to live together, the will to perpetuate the value of the heritage that one has received in an undivided form". ${ }^{16}$ Renan's will of the people can be compared to Anderson's notion of the imagination - both intangible, both presumably the exercise of free choice. However, the multifariousness that is the result of colonial history upsets the ease with which the willing of the nation into being or the imagining of the nation can take place.

In fact, Chin Kee Onn suggests that the strength of the Japanese empire is its capacity to homogenize its various parts, to remake its conquered territories into its own image:

Such were the social and political metamorphoses which went on in Malaya. The country was "japanised" if you might use the term. The older 
generation looked on helplessly with cynical composure. Theirs was an outward acceptance of everything. The real danger lay with the young and coming generations. They were the ones that mattered. And the Japanese saw to it that the young plastic minds should be moulded according to Japanese ideas.

Judging by the stupendous rate of the assimilation of Japanese propaganda by the conquered peoples, Japan, given five years of uninterrupted lordship over East Asia, would have laid down for herself a foundation for her Imperialism which would be most difficult to destroy.

Given a further five years, her programme of Nipponisation would be so consolidated that all East Asia would be thoroughly conquered politically, economically, spiritually and culturally. (Malaya Upside Down, p. 155)

The more an empire is able to homogenize itself into a nation, the more sturdy its foundation. For Chin, it is a bitter irony that the desired process of homogeneity occurs under the hated Japanese rule. Given enough time, Malaya might have comfortably settled into Japanese imperialism as it did with British imperialism.

The multifariousness is the legacy of the old empire to the new nation. For instance, the current debate in historiography over the "British problem" - whether to study Britain as a whole, or to study the various national histories - arises because the Welsh, Scots and the Irish have not forgotten their ethnicity/race. Empire is that which is all-inclusive, all enclosing, even rapacious in its ability to incorporate and consolidate foreign elements within itself. The nation, however, presses toward homogeneity so that the unassimilated and unassimilable elements experience another kind of colonialism - the situation of the Aborigines of Australia is a fine example of this internal colonization. Unable to make their claims be taken seriously, do they not then perceive the nation as a suppressive empire? Frantz Fanon, too, argues that homogeneity forms the foundation of the decolonized nation: "We have said that the colonial context is characterized by the dichotomy [between colonizer and colonized] which it imposes upon the whole people. Decolonization unifies that people by the racial decision to remove from it its heterogeneity, and by unifying it on a national, sometimes a racial, basis". ${ }^{17}$ The distinction I am making here blurs at times. For example, Chin's analysis of the "japanisation" of Malaya shows that empire too can be homogeneous, and as I shall show with Chin's conception of Malayan nationalism, a multifarious nation too can be sustained. But it is a useful enough distinction in that it highlights the tension between multifariousness and homogeneity. This tension means that the late twentieth-century world is caught between empire and nation. The problem of ethnicity means that Malayan (later to be Malaysian) authors like Chin Kee Onn are adapting the model of empire to fashion the new nation and the discourse of nationhood is "contaminated" - to use Chin's metaphor - by the heterogeneity of the empire, as Yeap's statement on 
pigeon-holes in Malaya may suggest. How then, out of contamination are a nation and a nationalism forged?

Chin Kee Onn's answer is to locate contamination elsewhere, displacing it onto corrupt Malayans who become Japanese collaborators, such as the character Fai Kua in Ma-rai-ee, who in co-operation with the Japanese Kempeitai (military police) bleeds the Malayans of their wealth and acts as a pimp for the Japanese officers. Fai Kua is even willing to cheat his own niece, Susy, of her property and to sacrifice her to the lust of the chief of the Japanese in his town. This breakdown in proper familial relations is symptomatic of the breakdown in normal relations in the greater family of the nation. While in Malaya Upside Down, heterogeneity is racial, in Marai-ee racial heterogeneity turns out to be a red herring:

I know there are secret societies sworn to destroy the Japs. I know there are Communists, adherents of the Marxist doctrine, who are fighting the Japs. I know there are groups of bandits, mere gangsters these, who are masquerading as patriots or members of this and that anti-Japanese league, who terrorize both the Jap agents and the public. Also, there are Kuomintang followers who have formed units of resistance here and there. In many of these organizations are Malays and Indians. So, you see, the vendetta is a common one, and the foe is a common one. But the motives of the various groups are vastly different. We are only concerned with revenge to propitiate our dead and to satisfy ourselves. We have no ulterior motives. But the secret societies are out for power. There is no doubt about that. I have also heard Communists talk of establishing a Malayan Republic. It is too early yet to delve into what that means. The gangsters who live on chaos, of course, play a double game for selfish gain.

In summing up, I would say that the underground movement has become hydra-headed. It has become a tangled mass with dangerous repercussions for the future. I dare not look too far into the future. I dare not say how things will turn out. I can only say that it is unfortunate that we've unwittingly become a part of the scheme of things. (Ma-rai-ee, pp. 121-22)

There are Malay and Indian members of (Chinese) Kuomintang resistance groups, and it is implied that the bandits are of all races. The problem turns out to be political heterogeneity. Even the presence of a "common foe", which unifies Malayans in a fashion, is not sufficient for a truly national consciousness with such diverse motives dividing the nation. The Communists, briefly alluded to here, become a greater and more menacing threat as the novel comes to its close. In the end, after the Japanese have been defeated, the Communist Malayan Peoples' Anti-Japanese Army (MPAJA) takes over and the narrator wonders, "But was Malaya truly liberated? Or had we merely exchanged the thraldom of the Japs for the thraldom of the Communists?" (p. 252). So, Chin identifies contamination successively as the Japanese fifth columnists, as the Japanese collaborators and finally as the communists. The narrator contrasts the Communists to 
his compatriots of the Anti-Japanese Organization (AJO): "The more I thought of them [his friends] and pondered over each one's worth, the more I realized that the things that count in life are character, courage, loyalty, and adherence to right principles ... those who died sacrificed their lives fighting an enemy who had enslaved and tortured Malaya" (p. 253). The AJO members are fighting for the re-establishment of the peaceful Malayan nation while the communists create havoc when after the end of the Japanese régime they try to punish those who collaborated with the Japanese.

The threat posed by the communists after the war, when the British had to establish a military government (the British Military Administration), appears in the way that Chin distances his characters - true Malayans from any implication of affiliations with Communism. It is particularly crucial because his characters are mainly Chinese and the communistdominated MPAJA is also Chinese-dominated. Again and again, Chin's characters emphasise that their anti-Japanese activities are personal, not political. The narrator of Ma-rai-ee concedes that the "Japanese were no worse than conquerors of the past or of recent times, for history has records of barbarities that put civilization to shame" (p. 76) and that they needed to establish their authority. He insists, "I just hated them because they had murdered Aunt Ho, whom I respected to the point of adoration, and because they had raped my cousins Su Fa and Su Mei" (p. 76). When the narrator is captured by the Japanese and interrogated about AJO, which they believe to be a communist organisation, he says, "I'm no Communist. I'm just anti-Japanese. I'm anti-Japanese because your beastly soldiers have slaughtered my people" (pp. 145-6). At the end of the book, when AJO is invited to join the League of Freedom Fighters, those who oppose amalgamation argue, "we were not a political body and we had no political axe to grind" and "as soon as that [Japanese] régime collapsed, our work would be done and there would be no further justification to continue its existence as a fighting group" (p. 228). Chin Kee Onn's novel is unavoidably a product of its time. The vehemence of the narrator's denial that his acts are political testifies to the the novel's pre-independence publication date and to its intended English audience.

We find in Chin's Ma-rai-ee, then, a peculiar form of nationalism - the advocation of diversity within unity. The "Chineseness" of his characters is acknowledged - in the names, in the setting of tin-mining region and, most interestingly, in the Japanese misidentification of the AJO as communist. But the Chinese identity of the narrator and other characters are linked to their identities as Malayan by their insistence on their difference from other undesirable, immoral Chinese like the collaborator Fai Kua and the communists. I argue that this unity has to be maintained against the lingering remains of empire for the hyphenated definition of citizenship - the 
Malaysian-Chinese or the Malaysian-Indian - tends to surface. Chin's novel tries to make of this (possibly unpromising) material a singular nationalism. This singularity is achieved partly by eliding out the other races. The Malay Halisamat and the Indian Jangitta Singh, finally, have only very small roles to play in Chin's drama. Chin defines the struggle of the war as one between the good Chinese and the bad, which allows him to define the good Chinese as true Malayan patriots and so to develop a Malayan-Chinese subjectivity.

Because Chin is so careful to avoid any imputation of Communism, his chosen stance of apoliticalness is somewhat disappointing. The closest thing to a political declaration in Ma-rai-ee is more or less a paean to British justice. Susy, who joins the group after being rescued from near-rape, argues that revenge is not a sufficient reason for the AJO's existence:

She spoke with a vitality I had not noticed before. She began by asking a question: "What are we fighting for? Is it merely to satisfy the desire for vengeance?" There was a pause, and she looked at each one of us in turn. Then she went on:

"I suggest that we are fighting for things beyond that. I would say that we are fighting to restore a way of life we have lost. Foremost of all, we've lost freedom. Cooped up in this house for months now like a caged animal, I know what freedom means. We used to live without fear, for British laws were just. Everybody was sure of a fair hearing, and policemen were the protectors of the people. Everybody lived contentedly according to their means. Rice was cheap, and living was cheap. There was no want in the land. Men had character. They were loyal to parents and their families. They were respectful to women. (p. 123)

Yet within the constraints of Susy's speech on the justness of British law and the narrator's denial of any affiliation with communist politics Chin Kee Onn still manages, I think, to delineate a kind of Malayan nationalism. It is a moderate one, obviously, based on a familial, or filial, model of good citizenship. It is a nationalism where order reigns and material needs are fulfilled. Unsurprisingly, Chin ends the novel by having the narrator reflect on the families who are Malaya's saving grace: "The moral backbone of Malaya - its average educated middle-class family - did not crack up. Malaya had its morons and imbeciles, but it also had its middle-class families in which were found its silent heroes and heroines... They were the redeeming feature of Malaya, for they fought a continuous moral war, and, although battle-scarred, were undefeated" (p. 254). In Malaya Upside Down, Chin had already written more fully on the role that the middleclass Malayan families play in maintaining a core Malayan identity despite the contaminating influences of Japanese imperialism:

While the Communists and the Guerillas fought an active physical war against the Japanese with knife, and gun, and hand-grenade, these, the silent sufferers, the silent army who might so easily be overlooked, fought a continuous moral war, a war of passive resistance, against the corroding 
forces of evil, so that human beings can still lift up their heads and say that they have not forgotten decency, loyalty to principles, sincerity, and uprightness. (p. 167)

It is these values of "decency, loyalty to principles, sincerity, and uprightness" that constitute for Chin a viable nationalism for the future. We have also seen how the importance of the family leads Chin to emphasize the bond of the multi-racial community of survivors of the massacre at the tinmine: "we decided to stay in the cave until the spate of Japanese fury had abated. Meanwhile the feeling of comradeship grew. We pulled together and understood each other more and more as the days went by, and a bond was gradually forged that transcended mere friendship" (Ma-rai-ee, p. 67). With this community, Chin expresses the possibility of an ideal multi-racial Malayan nation. It is significant that for such a nation to exist, familial ties must be forged.

Chin's ideal family includes the British. Three soldiers - two Australians and a Scotsman - join the group. And even relations among these British soldiers provide a model of what a utopian community ought to be, for "All rank between them had been laid aside" (Ma-rai-ee, p. 64). Even if Chin Kee Onn only manages to articulate explicitly a limited nationalism that does not - or dares not - name the ultimate end of the Malayans' moral war to be independent from British imperialism, the relationship between the Malayans and the British soldiers in the novel implicitly suggests a revising of colonial relations. When one of the soldiers gives Suet Wan the nickname Susy, she in turn gives the soldiers Cantonese nicknames - Kolo (tall man), Wuso (bearded man) and Taipei (big nose) - mocknames, really, which they keep for the rest of the novel. Perhaps it is with these British soldiers, who take on a kind of Malayan identity with their new names, that Chin tries to achieve a kind of pourissement, the absence of which he laments in Malaya Upside Down. Moreover, when they propose starting a vegetable garden, the soldiers jokingly say, "it's high time we had brown skins" (p. 67). Later, while they reconnoitre the jungle with other AJO members in their guerilla warfare, the British soldiers have their skin and hair darkened "with dyes prepared from Sakai [Malayan aboriginal] formulae" so that "Only at close range could strangers make out the soldiers to be European, for then they are given away by the colour of their eyes" (p. 121).

The absorption of the British soldiers into the Malayan family is fostered by the mediating figure of the woman. At the cave where the soldiers first meet the Malayans, "They were immediately attracted by Suet Wan and began to take an active interest in her" (p. 64). It is Suet Wan, renamed Susy, who brings the soldiers into the inner circle of the family by giving them Chinese names. Susy also serves as a unifying figure for the other Malayan characters - her courage serves as an encouraging example for 
the men. The narrator himself is attracted to her. But the possibility of romance, once brought up is immediately stifled. The soldiers are unable to communicate with Susy except through an interpreter because she only speaks Cantonese, while the narrator is a married man. Nonetheless, the energy generated by romance in an odd way drives the anti-Japanese activities of the group. After all, Susy is the one who teaches them to fight for freedom. She also unwittingly teaches them to be selfless when they rescue her from her Japanese attackers. The new nation, organized on the model of the family, depends on the woman to facilitate its birth. Having fulfilled her role, Susy dies at the end - indeed, has to die because for the narrator to have a sexual relationship with her would be morally repugnant. Instead, the narrator thinks of his lost wife, Li Lan, who has presumably escaped to India. The last words of the novel are those which the narrator records in his diary, telling of his determination to find $\mathrm{Li}$ Lan, whom he thinks will save him from the bitterness that he has lived through during the occupation: "My salvation lies with $\mathrm{Li}$ Lan.... What is Liberation, what is Life, if I cannot find Li Lan?" (p. 254). The search for the lost wife is crucial to the new nation. It is significant then that she is not yet found. The narrator, as yet, can only express his desire to search for her. In 1952, we still await the granting of independence.

The new familial nation, however, is foreshadowed by the ideal multiracial community of the cave, shown to be far superior to both the oppressive Japanese régime and the dying British empire. The narrator contrasts the three assimilated soldiers with British and Australian prisoners-of-war:

When I saw how the Japs had turned these Tommies and Aussies into halfnaked scavengers of the lowest order, vulgarly stared at, gibed at, and at times spat at, I could not help feeling that there must be many among them who cursed the day they surrendered. These wretched prisoners-of-war were paying the penalty of an Imperial tragedy.

Then I thought of Kolo, Wuso, and Taipei. How fortunate they were to have escaped such a humiliation! (p. 85)

Implicit here is the suggestion that the three British soldiers' fortunate escape depends on their willingness to assimilate and to discard their former racial privilege. By alluding to an "Imperial tragedy", the narrator hints that change in British attitudes is in order. Chin is more forthright in Malaya Upside Down:

But the British have this consolation. They have not returned to a hostile population. They have returned to a family of mixed races, who have had enough of Japanese tyranny and injustice. Malayan people had suffered enough - their mouths had been sealed; their hands and feet shackled; their ears plugged; their minds drugged. But out of these tribulations have arisen a people who have learnt to discriminate between justice and injustice, between sincerity and hypocrisy, between good and bad. The British will 
find a people resentful of oppression and official bigotry, but responsive to wise and kindly leadership. Out of the bitterness of their experiences, the Malayan people have learnt to appreciate Justice, Freedom, and Good Government.

The British will find that the people of this new Malaya are vitalised by a new political outlook, so that they should not be surprised if they do not find the former docility and limp submissiveness to authority.

It is only by sympathy and understanding of a people who have gone through the throes of a re-birth that there will emerge Peace, Common Prosperity, and Co-operation Absolute. (p. 208)

Chin emphasizes the familial aspect of the new nation - "a family of mixed races" - but refrains from advocating any concrete political reforms. His language is filled with vague abstract terms though he does maintain that there has been a discernible change in the people who have been through the trauma of the occupation. Chin's circumspection is perhaps warranted; in the negotiations for independence that were underway during the time the British showed a preference for working with pro-British moderates, and pursued a policy of harassing the increasingly isolated political left, eventually forcing the militant Malayan Communist Party, which demanded the outright end of colonialism, into the resumption of guerilla warfare, this time against the British - an armed struggle that launched the period euphemistically referred to as the "Emergency". ${ }^{18}$

In her analysis of trauma in Freud's Moses and Monotheism, Cathy Caruth argues that in Freud's account, the history of the Jews is one of departure - exodus - a "departure that is both a radical break and the establishment of a history" and with it the "repression of a murder [of Moses]". Caruth's reading of the fort-da game in Freud's Beyond the Pleasure Principle further emphasizes the importance of departure: "the game of departure and return is ultimately, and inexplicably, a game, simply of departure". ${ }^{19}$ I borrow Caruth's insight into the significance of departure in the experience of trauma to suggest that the trauma of the Pacific War is not simply that of suffering Japanese cruelty and the material deprivations of war-time but is defined crucially by the departure of the British colonialists both in actual fact during the months leading up to the Japanese invasion and symbolically. Tan Sri Abdul Aziz bin Zakariah, who lived through the war, writes in his memoir:

It is quite clear that had it not been for the Japanese Occupation, colonial rule would have continued in the country.

Before the War, it was thought that the British were all powerful.... There was, at that time [pre-WWII days], very little resistance against the colonial power by the population because, after centuries of colonial rule, the will to fight back was not very strong. It went to the extent that the local population thought the colonial power was all powerful and it was impossible to fight them. 
The Japanese invasion changed all that. What was thought to be a very strong colonial power was actually beaten by an Asian power, i.e. the Japanese. From then onwards, it was very difficult for any occupying power to hold the country for any length of time. ${ }^{20}$

It is thus a productive trauma that allows for a radical break with colonial history and the establishment of a new nation. There is a suggestion here in Abdul Aziz's analysis that the nation's independence is the resolution of an Oedipal struggle. Before the colonized subjects can break out of the yoke of imperialism, the "all-powerful" paternal figure of the British rulers has to be symbolically killed by a murderer that looks very much like the subjugated self - "an Asian power". For Abdul Aziz, like the child's break from the parent, the departure of the colonial masters is absolute and final, and there can be no return. In her autobiography, Yeap Joo Kim makes the father-child relationship between colonizer and colonized explicit: "The British had surrendered and our hopes were shattered. We felt betrayed. They had kept us innocent and naive, like children of a benevolent father. Now the father had abandoned his children and for the first time in our lives, we knew real terror". 21

In Ma-rai-ee, Chin re-enacts the traumatic British departure by killing off the three British soldiers in stages. By the end of the novel, even the leader Kolo is dead, murdered by the Japanese. In post-war Malaya, of the initial community, there remain only the Malayans. In his novel, Chin Kee Onn suggests that leadership needs to be passed on from former British colonialists to new citizens of a post-colonial nation. The Freudian murder of the British father, however, is complicated by the presence of another strand of narrative. It is the women who drive the plot of Ma-rai-ee. In the beginning, in order to pay his last filial respects to his dying mother, the narrator journeys from Singapore northwards to Ipoh, and thus, closer to the advancing Japanese army. He is caught in the war and is one of the hundred-odd people sheltering in the tin-mine. So it is a woman who, unwittingly, embroils the narrator in the war. Otherwise, he might have fled Singapore as his wife would do later; but flight would be a cowardly and an irresponsible act. After the massacre, the rescue of Susy prompts the small band of survivors to formulate a concerted effort in resisting the Japanese. Susy, as I have argued, becomes the central figure around whom the underground resistance group unites. And at the end of the novel, after Susy's death, the narrator looks to his lost wife for his salvation, and implicitly, the salvation of the new nation about to emerge. Women play a crucial, though limited, role - largely as inspiration for the men. Limited that role may be, at every important turning-point it is the woman who enables the new nationalism to emerge and to mature. Chin articulates a discourse of the Malayan mother-wife to replace that of the imperialist British father. Finally, in both Malaya Upside Down and in Ma-rai-ee, Chin 
argues that in fact that the war has changed colonial relations and has created a Malayan nationalist subject who has proven himself worthy of inheriting a post-colonial nation. What form that nation takes, however, is not fully articulated by Chin. We have to turn to later works like Fernando Lloyd's Scorpion Orchid (1976) and Green Is the Colour (1993) to find the post-colonial nation examined in Malaysian fiction.

\section{NOTES}

I would like to acknowledge the Midwest Conference for Asian Affairs (MCAA) for their Percy Buchanan research award, which supported, in part, the preparation of this essay for publication.

1 Although prior to World War II the region had experienced arguably traumatic events including colonization by a succession of European powers - the Portuguese, the Dutch and the English - the difference with this war was that it was experienced by all of the several races who now make up Malaysia's multiethnic citizenry. For it was after World War II that the Chinese and Indians, who, beginning in the mid-nineteenth century, came to work for the British as unskilled labourers, decided to remain in Southeast Asia permanently.

2 For a sense of the extent of this body of work, see Justin J. Corfield, $A$ Bibliography of Literature Relating to the Malayan Campaign and the Japanese Period in Malaya, Singapore and Northern Borneo, Bibliography and Literature Series Paper No. 57, Centre for Southeast Asian Studies, the University of Hull, 1988.

3 For work on local history (rather than national), see Pendudukan Jepun Di Tanah Melayu, 1942-45 (Kumpulan Esei Sejarah Malaysia oleh Pelajar-Pelajar U.S.M.), eds. Paul H. Kratoska and Abu Talib Ahmad, Pulau Pinang, Malaysia: Universiti Sains Malaysia, 1989. Recent scholarship on Malayan literature of the period includes Wong Yoon Wah, "Chinese Writers and the 'War-Resistance Literature' of Malaya and Singapore, 1937-1942", in A Sense of Exile: Essays in the Literature of the Asia-Pacific Region, ed. Bruce Bennett, Nedlands, Western Australia: Centre for Studies in Australian Literature, University of Western Australia, 1988, pp. 131-43; Leong Liew Geok, "Alienation and the Pacific War: The Fiction of Lim Thean Soo and Chin Kee Onn", in A Sense of Exile, pp. 145-54; Patricia Lim Pui Huen's "Memoirs of War in Malaya", in Malaya and Singapore During the Japanese Occupation, Journal of Southeast Asian Studies Special Publication Series No. 3, ed. Paul H. Kratoska, Singapore: National University of Singapore, 1995, pp. 121-47. Patricia Lim includes a short bibliography of Malayan autobiographical writings in an appendix. Leong Liew Geok also notes that Lim Thean Soo has completed an as yet unpublished novel on the Pacific war titled The Towkay of Produce Street (p. 153, note 4).

4 As anachronistic as it may seem to speak of the post-colonial subject in the context of a novel written before Malaysia's independence in 1957, the term "post-colonial" is a useful shorthand to capture the sense of the shift in the balance of power in Anglo-Asian relations that I detect in Chin's novel.

5 Anderson, Imagined Communities: Reflections on the Origin and Spread of Nationalism, rev. edn. London and New York: Verso, 1991.

6 Chin, Ma-rai-ee, London: George Harrap, 1952, first published as The Silent 
Army, London: George Harrap, 1952. The note on the title page informs us that "Maraiee was the name given to Malaya by the Japanese during their occupation of that country from December 1941 to August 1945, when for three and half years the lives of all Malayan people hung by a thread".

7 Chin, Malaya Upside Down, Singapore: Jitts, 1946. Further references are cited parenthetically.

8 Malay for watchman.

9 "Read This Alone - And the War Can Be Won", trans. G.W. Sargent, Appendix $\mathrm{I}$, in Colonel Masanobu Tsuji's military account of the war, Singapore: The Japanese Version, New York: St Martin's Press, 1960, pp. 302, 307-308, 309.

10 For an account of Japan's encouragement of nationalist movements in Southeast Asia (particularly Indonesia) prior to World War II, see Willard H. Elsbree's Japan's Role in Southeast Asian Nationalist Movements 1940 to 1945, New York: Russell and Russell, 1953.

11 Chin, Malaya Upside Down, Singapore: Jitts and Co., 1946, pp. 156-60.

12 Anderson, pp. 120-21, 123.

13 The present racial make-up of Malaysia is roughly $58 \%$ Malay and other indigeneous groups, $27 \%$ Chinese, $7.5 \%$ Indian, 3.2\% Others (includes Eurasian) and $4.3 \%$ Non-Malaysian. These percentages are my own calculation based on figures of the census of August 1991 taken from demographic and statistical information on Malaysia in The Far East and Australasia 1997, London: Europa Publications, 1996. The Statesman's Year-Book 1996-97, ed. Brian Hunter, London and Basingstoke: Macmillan, 1996, gives figures for 1980 that appear to have slightly different racial divisions, where the Orang Asli (aborigines - themselves made up of diverse tribes) are grouped under "Others". These figures are $47 \%$ Malay, $32 \%$ Chinese, $8 \%$ Indian and $13 \%$ Others.

14 Yeap, Of Comb, Powder \& Rouge, Singapore: Lee Teng Lay, 1992, pp. 477-8.

15 Christie, A Preliminary Survey of British Literature on South-East Asia in the Era of Colonial Decline and Decolonisation, Bibliography and Literature Series No. 3, Centre for South-East Asian Studies, University of Hull, 1986.

16 Ernest Renan, "What Is a Nation?", trans. Martin Thom, in Nation and Narration, ed. Homi K. Bhabha, London and New York: Routledge, 1990, p. 19.

17 Fanon, The Wretched of the Earth, trans. Constance Farrington, New York: Grove Press, 1963, pp. 45-6.

18 Chin Kee Onn subsequently wrote a novel on the Emergency years titled The Grand Illusion, London: George Harrap, 1961.

19 Caruth, Unclaimed Experience: Trauma, Narration, and History, Baltimore and London: Johns Hopkins UP, 1996, pp. 14, 66.

20 Abdul Aziz, British, Japanese and Independent Malaysia: A Memoir, Malaysia: Institut Tadbiran Awam Negara [National Institute of Public Administration], 1989, pp. 23, 126.

21 Yeap, p. 100. 